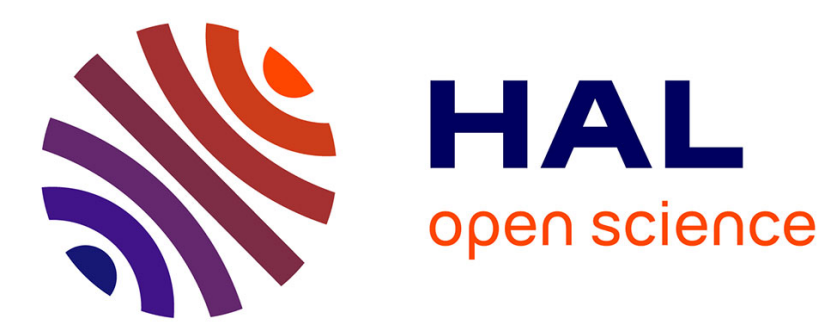

\title{
Sinotragus (Bovidae, Mammalia) from Turkey, and the Late Miocene Middle Asiatic Province
}

Denis Geraads, Erksin Güleç, Tanju Kaya

\section{To cite this version:}

Denis Geraads, Erksin Güleç, Tanju Kaya. Sinotragus (Bovidae, Mammalia) from Turkey, and the Late Miocene Middle Asiatic Province. Neues Jahrbuch für Geologie und Paläontologie Monatshefte, 2002, 2002 (8), pp.477-489. halshs-00009945

\section{HAL Id: halshs-00009945 https://shs.hal.science/halshs-00009945}

Submitted on 4 Apr 2006

HAL is a multi-disciplinary open access archive for the deposit and dissemination of scientific research documents, whether they are published or not. The documents may come from teaching and research institutions in France or abroad, or from public or private research centers.
L'archive ouverte pluridisciplinaire HAL, est destinée au dépôt et à la diffusion de documents scientifiques de niveau recherche, publiés ou non, émanant des établissements d'enseignement et de recherche français ou étrangers, des laboratoires publics ou privés. 
Sinotragus (Bovidae, Mammalia) from Turkey, and the Late Miocene Middle Asiatic Province

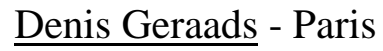

Erksin Güleç - Ankara

and

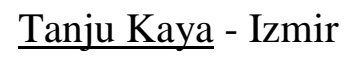

Abstract: The Late Miocene Yatağan Formation near Muğla (Turkey) has yielded several specimens of the Bovid Sinotragus, a genus previously known only from Shanxi, China. Among Ungulates, the Rhino Chilotherium, the Giraffid Samotherium and the ovibovines of the Plesiaddax-Urmiatherium group had a similar geographic range. They are undoubtedly open country forms, which attest the extension of such an environment across the whole of Asia around $35^{\circ} \mathrm{N}$ in Late Miocene times. The discovery of Sinotragus in Turkey thus confirms an idea already put forward 50 years ago by B. Kurtén.

\section{$\underline{\text { Introduction }}$}

The Late Miocene Mammalian faunas of Turkey, despite their richness, are still rather poorly known. Except for a few localities, such as Kemiklitepe (Sen $\&$ al. 1994) and perhaps the

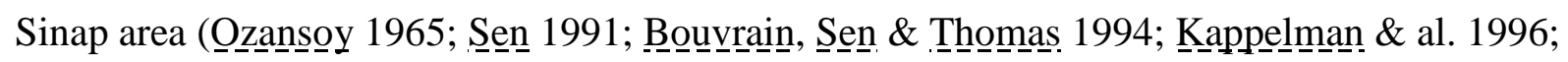
Geraads \& G Güleç, 1997, 1999; Lunkkㅡㅁ \& al., 1999; other studies in progress), most of the richest fossiliferous sites are known only through faunal lists and short reports, often outdated today, with unreliable identifications. A German team led by O.Sickenenberg conducted important field work in the 70s, but of the taxa that they reported (Sickenberg \& al 1975), only the

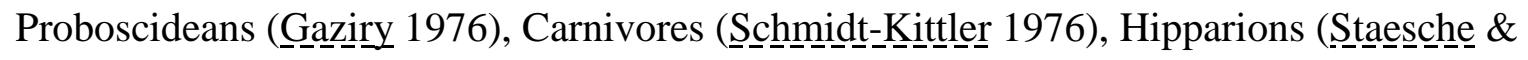
Sondaar 1979) and Bovids (Köhller 1987) have been described, and this important work remains therefore incomplete. However, various Turkish Institutes house unpublished collections whose study could greatly improve our knowledge of these Late Miocene faunas, both from the biostratigraphic and biogeographic aspects. One of them comes from the Muğla area, in western Turkey. The first fossiliferous localities near the villages of Akgedik and Bayir were found 60 years ago; Ozansoy (1951) published a preliminary faunal list of 10 taxa of large Mammals. Another site there (Eski Bayirköy) was mentioned by Becker-Platen (1970) and Sicken_-nberg (1976); they gave a longer but rather different faunal list. The most fossiliferous locality, Salihpaşalar (Kemikalan), was first recognised by A Atala area was first described in detail by Beeker-Platen (1970), and then by Atatalay (1980), who 
formally named the Upper Miocene Yatağan Formation, divided into 3 members, the most fossiliferous of which is the Bayir member, for which he (Atalay 1980) provided a faunal list. The Bayir member is widely exposed in southwest Anatolia (Fig.1). It consists of brownish mudstone, claystone, conglomerate, gray limestone and interstratified tuffite. The mammalian fauna occurs in the lenticular masses of brownish claystone. Our (Kaya 1991, 1994; Geraaㅁㅁㅛ \& Güleç 1999, and unpublished) Ungulate identifications of the fauna of this member are as follows: Hipparion mediterraneum, H. matthewi, Ceratotherium neumayri, cf Ancylotherium pentelicum, Orycteropus sp., Microstonyx erymanthius, Giraffid gen et sp. indet. (very large), Gazella sp., Palaeoryx pallasi, Protragelaphus cf skouzesi, Tragoportax sp. This list reminds that of Pikermi, and the age of the Bayir member must not be very different from that of the Greek locality, as already suggested by Kaya (1994).

We describe here a fourth Bovid from the same area; it is found in Akgedik-Bayir, at Salihpaşalar (Kemikalan), and perhaps at Örucebağ near Ankara. No name has ever been published for it, but some of the specimens are labelled Sinotragus wimani in the Maden Tetkik ve Arama (MTA) Museum, Ankara.

\section{$\underline{\text { Systematic description }}$}

Genus Sinotragus Bohlin, 1935

$=$ Prosinotragus Bohlin, 1935 ?

Type-species: Sinotragus wimani Bohlin, 1935: 133.

Original diagnosis: " Grosse Antilopen mit sehr kurzen, dicken, homonym gedrehten Hörnern. Der Schädel ist plump mit verdickten Knochen. Die Hörner können als abnorm entwickelte Prosinotragus-Hörner aufgefasst werden."

Sinotragus occidentalis n.sp.

Holotype: a relatively complete skull, lacking the anterior part of the muzzle, most of the teeth, and with a poorly preserved cranial base. $\mathrm{N}^{\circ} 1894$ in the MTA Museum, Ankara. Type-locality: Yatağan Formation, Bayir member, Akgedik-Bayir area (Muğla). Precise locality unknown.

Derivatio nominis: the species was found almost $8000 \mathrm{~km}$ west of the type species. Diagnosis: a Sinotragus about the size of S. wimani and S.? tenuicornis, but with a narrower skull. Long brain-case. Fronto-parietal suture extremely complicated. Differs from S. wimani by its smaller and less expanded horn-cores, with a strong postero-lateral keel, longer cranial basis, shorter temporal fossa, occipital more rounded. The lachrymal is more expanded on the face, the 
jugal less so. Differs from S. tenuicornis by its horn-cores which are more like those of S. wimani.

Hypodigm: From the type-locality, there are also the posterior part of a skull with an incomplete horn-core, $\mathrm{N}^{\circ} 1762$ in the MTA Museum, and a frontlet in the Izmir Museum. Two frontlets from Salihpaşalar (Kemikalan) are also in the MTA Museum ( $\mathrm{N}^{\circ}$ MYK-75-573 and 580). As there is no doubt that these specimens belong to the same species, they will be described with the type. A few more specimens, of less secure identification, will be described separately. Descriptions and comparisons: The anterior part of the muzzle is missing on all specimens. An ethmoidal fissure is present, as well as a preorbital depression with a ridge-like upper border. The lachrymal is longer than in S. wimani, as it expands farther anteriorly than the jugal, which lacks an upward extension along the orbit (Fig. 2A), in contrast to S. wimani (Bohlin 1935, fig.108). The orbit is perhaps relatively larger and more circular than in S. wimani, with a projecting rim. Only two much worn molars remain on the type; they had weak or absent basal pillars, and they cannot be distinguished from those of S. wimani, which are rather variable (Bohlin 1935: 148).

The supra-orbital foramina are small, and almost roofed over by an anterior expansion of the horn-core. The frontal bone is thick, but there is a single large sinus at the base of the horn pedicle. The inter-frontal suture is clearly visible, and the area just anterior to the parietal is raised and pinched transversely so as to produce a characteristic hump just behind the horncores (Fig. 2C). Bohlin (1935) mentioned a similar feature in S. wimani. There is no postcornual fossa. The fronto-parietal suture is extremely complicated, especially laterally (Fig. 2C), perhaps more so than in any other Bovid. According to Bohlin (1935), the fronto-parietal suture of S. wimani is "fast gerade", but he probably meant "not curved" rather than "simple". Furthermore, the lateral part of the suture was probably overlapped by the basal horn-core expansion in S. wimani.

The braincase is strongly inclined in respect to the facial axis. The temporal lines are weak. The occipital is more regularly rounded than that of S. wimani and the mastoid exposure is not so broad (Fig.2E). The basi-occipital has almost no anterior tuberosities, being transversely convex at this level. The tuberosities are stronger in S. wimani, with a central groove. The temporal fossa is extremely short, being broader than long on $\mathrm{N}^{\circ} 1762$, which is not deformed.

The horns are inserted uprightly and close together (Fig. 2B). On $\mathrm{N}^{\circ} 1762$, which we interpret as juvenile, there is a distinct pedicle, but on $\mathrm{N}^{\circ} 1894$, which is old (as shown by the teeth), the external rugose part of the horn-core has grown downwards, tending to cover the 
supra-orbital foramina, and to spread out on the posterior part of the frontal (Fig. 2C). The horncores are less massive at the base than those of S. wimani and they do not taper so quickly, but they have a similar course, being almost parallel and strongly curved backwards. Torsion is absent on the holotype and on $\mathrm{N}^{\circ} 75-573$, not detectable on $\mathrm{N}^{\circ} 1762$ which is incomplete, and weak, of the Oioceros type, on $\mathrm{N}^{\circ} 75-580$, which is the most wimani-like.

On $\mathrm{N}^{\circ} 75-580$ only, the front part of the base of the horn-core is somewhat inflated and pitted rather than grooved. The section at the base is more or less triangular, sometimes very clearly so, with a medial face which is slightly posterior and becomes more so upwards, an antero-lateral surface which becomes more anterior (topographically, superior) and a posterolateral one which becomes more lateral (topographically, infero-lateral). The anterior keel is not distinct basally, but becomes sharp upwards, as in S. wimani (Bohlin 1935, fig.118). The postero-lateral keel is stronger, and even ridge-like on the type and on $\mathrm{N}^{\circ} 75-573$; on these specimens, it is even expanded as a lateral flange in the basal part of the horn-core. There is no postero-lateral keel in S. wimani.

\section{Female specimens?}

A few other specimens are doubtfully referred to S. occidentalis. They are much different from the specimens described above, and if they are really of this species, they must be juvenile, or more probably female. There is a frontlet from Akgedik-Bayir, $N^{\circ} 67$ in the Fen Fakültesi, Ankara, a horn-core $\mathrm{N}^{\circ} 13$ from Salihpaşalar in the Izmir Museum, and a horn-core from Örücebag in the Dil ve Tarih Coğrafya Fakültesi, Ankara, №̈B-48. Nothing of the skull is visible. The horn-cores are smaller than those described above, stout at the base, but taper quickly upwards, much as in S. wimani. They have an oval cross-section, without keels, are transversely compressed, and more convex laterally than medially. They are much curved backwards, and also outwards, and perhaps more clearly twisted. The horn-core from Salihpaşalar has an anterior pitted swelling, like the specimen $\mathrm{N}^{\circ} 75-580$ above.

These horn-cores come from the same strata as those of S. occidentalis. They share only a few features with them, but these features are unusual among Late Miocene Bovids, and they cannot be referred to any other known genus. Their cross-section, by which they differ from S. wimani and from (the males of ?) S. occidentalis, is rather similar to that of Prosinotragus tenuicornis, a poorly known species from Loc.116 of Qansu, China, whose horn-cores are less stout than those of the other species, and which has a semi-circular occipital, like that of S. occidentalis. The possibility that S. tenuicornis is indeed the female of S. wimani could also 
be considered, since there are only two identifiable specimens of the latter species at Loc.30, and one of the former at Loc.116.

\section{Phylogenetic relationships of Sinotragus}

Solounias (1981) referred Samotragus crassicornis Sickenberg, 1936 from Samos to Sinotragus, thereby sinking the former genus into the latter. Both taxa share a face strongly inclined on the cranial axis, a raised mid-frontal suture, and the direction of horn spiralling, but the latter is only incipient in Sinotragus, while it is very strong in S. crassicornis, as in the Oioceros-Samotragus complex. The cross-section is also much different, with a flattened medial side in Sinotragus from China and Muğla, instead of a more rounded cross-section with a flattened antero-lateral side in S. crassicornis. In our opinion, these genera are only distantly related.

Bohlin (1935) considered that Sinotragus was related to Protoryx, and this opinion was also held by Gentry (1971: 243). The main characters shared by the two groups are:

- large size;

- strong cranio-facial flexure;

- horns almost parallel at the base, curved backwards;

- sinus in the pedicle;

- complicated fronto-parietal suture.

Bohlin also noticed that the rectangular lachrymal bone of S. wimani is similar to that of his ? Protoryx planifrons.

However, the lachrymal of S. occidentalis, as well as those of other Protoryx species, are different. The other above-mentioned features are not exclusive of these groups; thus, they are not very convincing to establish a close relationship

Unfortunately, other hypotheses of relationships are perhaps still less satisfactory: - the triangular cross-section of the horn-cores (especially on the holotype of S. occidentalis) and some other minor characters suggest affinities with the Bovinae, but the rest of the skull is so different that this relationship is very unlikely;

- the narrow skull, strong cranio-facial flexure, and short stout horns are like the Ovibovines, but it now appears that this group might well be polyphyletic, if not a waste-basket (Gentry \& Heizmann 1996; Gentry \& al. 1998). In any case, the teeth of Sinotragus are rather different from those of the Upper Miocene so-called Ovibovines, and its horn-cores are made of compact bone, while those of the Ovibovines are usually cancellous. 


\section{The Middle Asiatic province}

It should perhaps first be mentioned that Solounias (1981) referred to Prosinotragus "a minute horn-core" from the Vallesian of Tunisia, probably the one illustrated by Robinson (1986, fig.10) The specimen is, however, undiagnostic.

In China, Prosinotragus and Sinotragus are known only from Loc.116 (Qansu) and Loc.30 (Shanxi). Both localities have yielded faunas of open character, that Kur.tén (1952) called the "dorcadoides"--fauna, from the specific name of its dominant gazelle. According to this author, this open environment extended, in the Late Miocene, as far as Turkey and the Black Sea, while Europe and the south-western part of China were more forested. Even though this model has been refined, it remains basically correct. Bernor (1984) called the SubParatethyan province an area extending from Northern China to Turkey, including also the Balkans. However, in the Balkans the few characteristic large Mammal taxa of this province are quite rare or absent.

One of them is the Rhino Chilotherium. There are a few records outside this area, but almost always without description; since fragmentary remains could easily be confused with other Rhinos, these few records can be taken as dubious, at the best. The only one worth to be considered is that of Ch. intermedium from the Dhok Pathan of Pakistan (Heisssig 1972), but this species is very different from typical species of the genus by its narrow mandibular symphysis and it certainly had a different ecology.

A second one is the Giraffid Samotherium, whose African records (Arambourg 1959; Churcher 1974) are probably erroneous. Among Bovids, the only previous markers of this province were the Ovibovines Plesiaddax-Urmiatherium, known from Baode (Loc.30) as well as

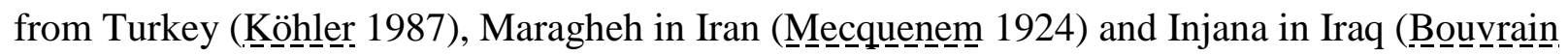
$\&$ al. 1995). Sinotragus can now be added to this list of taxa with a wide Asiatic range, but which are probably absent from the southern part of this continent, and from Europe and Africa. It should be noted that Hominoid Primates are absent from the sites which have yielded this typical association. It may be because all of them post-date the extinction of Hominoid Primates in the area, but ecological differences between contemporary faunas cannot be dismissed.

\section{$\underline{\text { Acknowledgements }}$}

Thanks to Baris Karabağli, Head of the MTA Museum, for providing access to collections. Travel expenses of D.Geraads to Turkey were funded by the CNRS. (UPR 2147 and Programme "Paléoenvironnement, évolution des Hominidés"). 


\section{$\underline{\text { References }}$}

Aramb-_oungrg, C. (1959): Vertébrés continentaux du Miocène supérieur de l'Afrique du Nord. Publ.Serv.Carte géol.Algérie. N.S. Paléontologie. 4: 1-159.

Atalalay, Z., (1980): Muğla-Yatağan ve yakin dolayi karasal Neojen'inin stratigrafi araştirmasi. Türkiye Jeoloji Kurumu Bülteni, C. 23: 93-99.

Bernor, R.L. (1984): A zoogeographic theater and biochronologic play: the time/biofacies phenomena of Eurasian and African Miocene Mammal provinces. - Paléobiologie continentale, 14 (2): 121-142.

Becker-_Platenen, J.D. (1970): Lithostratigraphische Untersuchungen im Känozoikum SüdwestAnatoliens (Türkei). - Beih.Geol.Jhb., 97: 1-244.

Bouvrain, G. Sen, S. \& Thhomas, H. (1994): Un nouveau genre d'Antilope dans le Miocène supérieur de Sinap Tepe en Turquie. - Revue de Paléobiologie, 13 (2): 375-380.

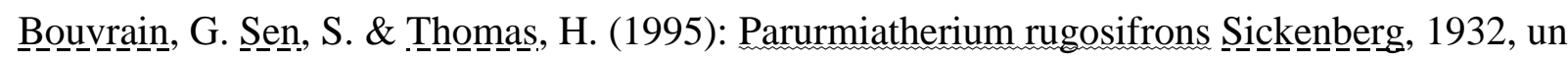
Ovibovinae (Bovidae) du Miocène supérieur d'Injana (Djebel Hamrin, Irak). - Géobios, 28 ( 6): 719-726.

Chhurcherer, C.S. (1970): Two new upper Miocene Giraffids from Fort Ternan, Kenya, East Africa: Palaeotragus primaevus n.sp. and Samotherium africanum n.sp. - Fossil Vert.Afr., 2: 1-106.

Gaziry, A. (1976): Jungtertiäre Mastodonten aus Anatolien (Türkei). - Geol.Jhb., B, 22: 1-143.

Gentry, A.W. (1971): The earliest goats and other antelopes from the Samos Hipparion fauna.Bull.Br.Mus.(Nat.Hist.)Geol., 20 (6): 231-296.

Gentry, A.W. \& Heizmann, E.P.J. (1996): Miocene Ruminants of the Central and Eastern

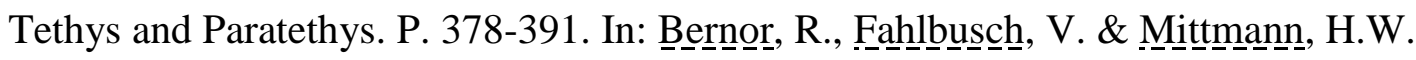
(eds): The Evolution of western Eurasian Neogene Mammal Faunas. New York (Columbia Univ.Press).

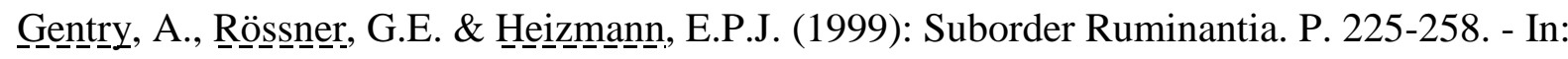
Rösssner, G.E \& He- $\underline{\text { eissig }}$, K., The Miocene land Mammals of Europe. München (F.Pfeil). Geraaa모, D. \& Güulleç, E. (1997): Relationships of Barbourofelis piveteaui (Ozzansansoy, 1965), an upper Miocene Nimravid (Carnivora, Mammalia) from central Turkey. - J.Palaeont., 17 (2): $370-375$.

Geraads, D. \& Güuleç, E. (1999): On some spiral-horned antelopes (Mammalia: Artiodactyla: Bovidae) from the Late Miocene of Turkey, with remarks on their distribution. Paläont.Zeitschr., 73 (3/4): 403-409. 
Heisissig; K. (1972): Paläontologische und geologische Untersuchungen im Tertiär von Pakistan.

5. Rhinocerotidae (Mamm.) aus den unteren und mittleren Siwalik-Schichten. -

Abh.Bayer.Akad.Wiss., Math.-Nat.Kl., N.F., 152: 1-112.

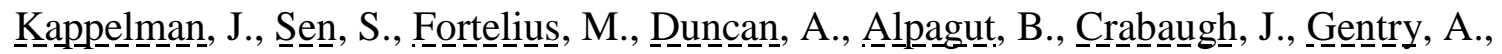

Lunkka, J.P., Mcㅁowell, F., Solounias, N., Viranta, S., \& Werdelin, L. (1996):

Chronology and biostratigraphy of the Miocene Sinap Formation of Central Turkey. P.

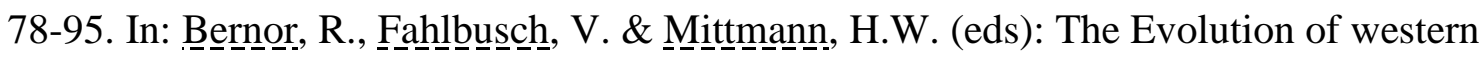

Eurasian Neogene Mammal Faunas. New York (Columbia Univ.Press).

Kayąa, T. (1991): Muğla yöresine ait Geç Miyosen yasli memeli faunalarindaki Perissodactyla

bulgulari. - Suat Erk Jeoloji Sempozyumu, 101-108.

Kaya, T. (1994): Ceratotherium neumayri (Rhinocerotidae-Mammalia) in the Upper Miocene of western Anatolia. - Turkish Journal of Earth Sciences, 3 (1): 13-22.

Köhller, M. (1987): Boviden des türkischen Miozäns. (Känozoikum und Braunkohlen der Türkei. 28). - Paleontología í Evolució, 21: 133-246.

Kurtén, B. B. (1952): The Chinese Hipparion fauna. - Soc. Scient. Fenn., Comment. Biol., 13 (4): $1-82$.

Lunkka, J.P., Fortelius, M., Kappelmann, J. \& Sen, S. (1999): 12 - Chronology and Mammal faunas of the Miocene Sinap Formation, Turkey. P. 238-264 - In: Agustí, J., Rook, L., \& Andrewss, P., The evolution of terrestrial ecosystems of Europe. Cambridge Univ.Press.

Mécquenenem, R. de (1924): Contribution à l'étude des fossiles de Maragha. - Ann.Paléont., 1924: $1-64$.

Ozansoy, F. (1951): Preliminary report on an Pontian Mammalian fauna from Muğla. - Bull.

Geol. Soc. Turkey, C, 3 (1): 147-152.

Ozans_oy, F. (1957): Positions stratigraphiques des formations continentales du Tertiaire de l'Eurasie au point du vue de la chronologie nord-américaine. - Bull. Miner. Res. Exp. Inst. Turkey, 49: 11-28.

Ozansansoy, F. (1965): Etude des gisements continentaux et des Mammifères du Cénozoïque de Turquie. - Mém.Soc.Géol.Fr., N.S., 24 (1): 1-92.

Robbinson, P. (1986): Very hypsodont antelopes from the Beglia Formation (central Tunisia), with a discussion of the Rupicaprini. Contrib.Geol., Univ.Wyoming, Spec.Pap., 3: 305315.

Schnmidt_-Kitttler, N. (1976): Raubtiere aus dem Jungtertiär Kleinasiens. - Palaeontographica, A, 155: 1-131. 
Sen- S. S. (1991): Stratigraphie, faunes de mammifères et magnétostratigraphie du Néogène de

Sinap Tepe, Province d'Ankara, Turquie. - Bull.Mus.Nat.Nist.nat., C, 12 (3-4): 243-277.

Sen-n, S., ed. (1994): Les gisements de Mammifères du Miocène supérieur de Kemiklitepe,

Turquie. - Bull.Mus.Nat.Nist.nat., C, 16 (1): 1-240.

Sickenenberg, O. (1976): Die Gliederung des höheren Jungtertiärs und Altquartärs in der Türkei

nach Vertebraten und ihre Bedeutung für die internationale Neogen-Stratigraphie.

(Känozoikum und Braunkohlen der Türkei). - Geol.Jhb., B, 15: 1-167.

Solounias, N. (1981): The Turolian fauna from the island of Samos, Greece. Contrib.Vertebrate Evol., 6: 1-232.

Staesche, U. \& Sondaar, P.Y. (1979): Hipparion aus dem Vallesium und Turolium (Jungtertiär) der Türkei. - Geol.Jhb., B, 33: 35-79. 


\section{Captions to figures}

Fig.1. Map of the Muğla - Yatağan area of Western Turkey, with the extension of the Bayir member of the Yatağan Formation, according to Atalay (1980).

Fig. 2. Sinotragus occidentalis n.sp. from Akgedik - Bayir. A-C: holotype, MTA 1894. A: left lateral view; B: antero-superior view; C: detail of the fronto-parietal area. D-E: MTA 1762. D: upper view of the brain-case and base of right horn-core; E: occipital view. Scale $=6 \mathrm{~cm}$ for AB, $4 \mathrm{~cm}$ for C-E.

Fig.3. Sinotragus occidentalis ? female specimen ? from Akgedik-Bayir. Science Faculty, Ankara. A: left lateral view; B: anterior view. Scale $=3 \mathrm{~cm}$. 
Table 1. Skull measurements of Sinotragus occidentalis n.sp.

\begin{tabular}{|l|c|c|c|c|}
\hline Number & $\mathbf{1 8 9 4}$ & $\mathbf{1 7 6 2}$ & $\mathbf{5 7 3}$ & $\mathbf{5 8 0}$ \\
\hline Length of Frontal (straight line) & 107 & - & & \\
\hline Length of Parietal ( " & 50 & 46 & & \\
\hline Length from basion to M3/ & $\approx 113$ & 89 & & \\
\hline Height, from basioccipital to & & & & \\
\hline Fronto-Parietal suture & $86-$ & 83 & & \\
\hline Max. occipital width & - & 86.5 & & \\
\hline Bi-condylar width & - & $\approx 52$ & & \\
\hline Distance between temporal lines & - & 34 & & \\
\hline HoRN-CORES: & & & & \\
\hline Basal index & $72 \times 38$ & - & $59 \times 48$ & \\
\hline Pedicle index & $55.5 \times 31$ & $-\times 33.4$ & $51 \times 43$ & $48 \times 40$ \\
\hline Length (straight line) & 136 & - & $134+$ & $\approx 140$ \\
\hline Length (along anterior curve) & 165 & - & $160+$ & $\approx 175$ \\
\hline Max. width over pedicles & $71+$ & $2 \times 42$ & 87.5 & $\approx 87$ \\
\hline Min. distance between horn-cores & 5.5 & 7 & 7 & $\approx 10$ \\
\hline
\end{tabular}

Basal indexes of the ?female specimens:

$\begin{array}{cc}\text { Akgedik-Bayir } & 48.5 \times 31 \\ \text { Salihpaşalar } & 41.7 \times 29 \\ \text { Örücebağ } & 40.3 \times 25.9\end{array}$

